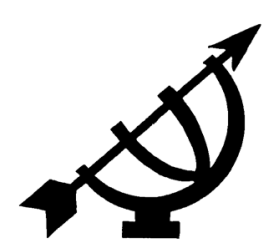

\title{
Critical prophecy and political leadership in biblical, African and Islamic worldviews
}

\author{
P.O. Abioje \\ Department of Religions \\ University of Ilorin \\ ILORIN \\ Nigeria \\ E-mail: poabioje@yahoo.com \\ poabioje@unilorin.edu.ng
}

\begin{abstract}
Critical prophecy and political leadership in biblical, African, and Islamic worldviews

This article examines the socio-political influence of prophecy in traditional African and the biblical perspectives, in order to challenge contemporary African religious men and women to serve as the conscience of society. There is hardly any doubt that political leaders are usually prone to abuse of their positions and they need to be reprimanded and lampooned. A discussion on Islam is included, because, together with Christianity, it dominates, to a large extent, socio-political and economic leadership in Africa. It is the view of many scholars that neither Christianity nor Islam have been applied sufficiently to political leadership in Africa to have an impact on mass socio-political and economic welfare, although some heroic individual exceptions are noted. The materials were gathered through a literature study. The study is comparative in the sense that it compares prophecy in traditional Africa with what is obtained from the Bible and the church as we know it today. The study recommends critical prophecy in the two dominant Old Testament religions, namely Christianity and Islam, and in African Traditional Religion, for improved political leadership and development in Africa.
\end{abstract}




\section{Opsomming}

\section{Kritiese profesie en politiese leierskap in bybelse, Afrika en Islamitiese wêreldbeskouings}

Hierdie artikel ondersoek die sosio-politieke invloed van profesie vanuit tradisionele Afrika- en bybelse perspektiewe ten einde kontemporêre Afrika-gelowiges uit te daag om as die gemeenskap se gewete te dien. Daar bestaan byna geen twyfel nie dat politieke leiers geneig is om hulle posisies te misbruik en hulle behoort mondelings sowel as skriftelik tereggewys te word. 'n Bespreking oor Islam word ingesluit, aangesien dit tot 'n groot mate, tesame met Christenskap, die sosio-politieke en ekonomiese leierskap in Afrika domineer. Dit is die uitgangspunt van menige navorsers dat sowel Christenskap as Islam oor die algemeen nie effektief in Afrika-politiek toegepas word om 'n massa-impak op sosio-politiese en ekonomiese welstand te hê nie, alhoewel sommige individuele heroïse geleenthede wel raakgesien word. Die materiaal is hoofsaaklik deur 'n literatuursoektog ingesamel. Hierdie artikel is vergelykend in die sin dat dit profesie in tradisionele Afrika vergelyk met dit wat oor die algemeen in die Bybel te vind is, sowel as met die kerk soos dit vandag daar uitsien. Die artikel stel kritiese profesie in die twee dominante gelowe van die Ou Testament, naamlik Islam en Christenskap sowel as in tradisionele Afrika-godsdiens voor, ten einde politieke leierskap en ontwikkeling in Afrika te verbeter.

\section{Introduction}

\subsection{Africa's leadership travail}

What is going on in Guinea, Niger and elsewhere is a direct consequence of the absence of role models among the power elite in most countries of sub-Saharan Africa. From Nigeria, Cote D'Ivoire, Benin, Cameroun, Togo, Niger to Kenya, Gabon, Zimbabwe and North Africa's Libya, whose Muammar Gaddafi is current $\mathrm{AU}$ Chairman, there is hardly anyone with the moral authority and political clout to caution Moussa Camara. ${ }^{1}$ (Anon., 2009:14.)

1 Moussa Dadis Camara was the military Captain who took over as Head of State of Guinea after the death of Lansana Conte, another military junta. Sittight African leaders, such as those mentioned in the quoted editorial, lack the moral power and justification to caution against the presidential ambition of Camara. 
The continent of Africa is thus perceived as plagued by corrupt and selfish leaders who propagate widespread poverty, in spite of the abundant human and material resources in many African countries. Turaki (1997:1 ff.) notes that "[t]he lack of moral will and ethical strength by leadership in Africa has been identified as the most serious issue and problem facing Africa today". There is no ulterior motive to say that Africa has no excuse for its lack of advancement several decades after achieving political independence from foreign colonialists, apart from the moral laxity of those who assume their leadership positions, and their resultant inability to work for the general good of their people.

\subsubsection{Purpose of study}

The objective of this article is to examine the socio-political influence of prophecy in the contexts of traditional Africa, the Bible, and Islam, with the aim of challenging contemporary African men and women to serve as the conscience of society. The author posits that African leaders are knowledgeable, and that they possess epistemological resources, but that not many of them have the patriotic zeal to use their positions to move the continent forward. This research is animated by liberation theology, which was born in Latin America in the late 1960s. Conn (1998:389) notes that,

Samuel Escober (b. 1934), an evangelical critic based in Peru, distinguishes three types of liberation - the pastoral one of Gutierrez; the academic emphases of Hugo Assrnan and Segundo; and a populist style which uses the language of liberation theology but remains old-style Catholicism.

This article tends toward the first two types. Basically, as Sweetland (1994:505) notes, "liberation theology seeks to recover the Christian commitment to transforming the world, being part of and making a contribution to the kingdom of God, and social justice". The ecclesiastical resistance to liberation theology is noted by many scholars, such as Conn (1998:388 ff.). My conviction is that liberation theology can promote the salvivic mission of Jesus Christ, which is both earthly and heavenly bound. This article seeks to highlight critical prophecy as an appropriate tool for those who seek political and economic justice, equity, and charity in African societies.

\subsubsection{Argument of the article}

The Yoruba of Western Nigeria have a proverb to the effect that when the leading cow derails, the whole flock goes astray with it. The proverb is used in reference to the pivotal role of a leader, and 
is reminiscent of Jesus Christ who is often quoted as calling Himself the good Shepherd (John 10:11). Yahweh is earlier depicted as the Shepherd of Israel (Ps. 23). Understandably, whenever any of the animals in the sheepfold is going astray, the good shepherd uses his staff to beat it back on track. The importance of the shepherd to a flock is also stressed in Mark 6:34 and 14:27. As a corollary, the leadership cadre of every nation is expected to possess the ability to guide the people intellectually, morally, and physically with the aid of security forces, such as the army and the police. Unfortunately, bad leaders ignore the rule of law and the courts, and abuse the security resources at their disposal. That is where critical prophecy should come in, as in the Bible and African Traditional Religion (ATR), where tyranny, oppression, and exploitation are condemned and sanctioned in God's name. Religious sanctioning of erring public officers may not be acceptable in a religiously pluralistic society, but criticism of evil perpetrators will always be cherished by people of good will and in this way it could contribute to social conscientisation.

\subsubsection{Beyond esoteric prophecy}

This article transcends the layman's conception of the figure of a prophet as a soothsayer by considering the prophet as someone who speaks divine words and engages in divine actions (such as protest activities against injustice) that can save or liberate people from oppressive and exploitative situations, and from ignorance. It is reminiscent of what Jesus did when He told his Jewish audience that the Sabbath was made for human beings, and not vice versa (Mark 2:27). Some scholars speaking of prophets as moral revolutionaries in a socio-political or economical sense are discussed below.

\subsubsection{Africa requires moral revival}

One of the starting points of this article is the conviction that critical prophecy, as opposed to the esoteric fortune-and-future telling type, allows a religion to contribute meaningfully and fundamentally to a society's progress, and socio-politically and economically, by being vigilant and critical of inhuman conduct. It follows the principle of see, judge, and act. In other words, critical prophecy is praxis oriented and can enable a religion to help ensure that the fruit of science and technology is distributed. equitably As Olukoshi and Nyamnjoh (2007:2) quote Joseph Ki-Zerbo: "African intellectuals should not be neutral in their submissions, when human lives are degraded, trivialised, impoverished, and wasted, as experienced in 
many parts of Africa." Indeed, one would agree with Dzurgba (2006:758) that "there should be a moral revival, renewal, reawakening and re-orientation in [the] cultural, social, economic and political thoughts and behaviours of the African people". The aim is, of course, to promote respect for the sacredness of human life, and commitment to social justice.

\subsubsection{The Islamic connection}

In the course of this research, it was found that one has to include Islam which, together with Christianity, dominates to a large extent socio-political and economic leadership in Africa. The literarature study was, therefore, extended to address the issue of ChristoIslamic political influence.

\subsubsection{The place of religion in human life}

This article considers it important that religion not be denigrated in favour of science and technology. As Catoir (1999:vi) notes, "All human behaviour is related to need, and need is often directly connected to one's religious convictions." To that extent, ATR, Christianity, Islam and any other religion can be tapped for instilling and actualising moral virtues, such as altruism, patriotism, and charity, without which social advancement may be arrested and endangered. It is in this way that critical prophecy proves its value and relevance.

\section{Prophecy in the Old Testament and in other cultures}

This subtitle may agitate some minds in which the assumption lurks that the prophetic phenomenon is limited to the Jewish tradition, with particular reference to the Old Testament (henceforth OT). That presumption has, however, been disproved by many scholars who have long discovered that prophecy had existed in the ancient Near Eastern nations before Israel came into existence as a society. As a general observation, Ellis (1963:28) notes the following:

An extensive list could be drawn up of the adaptations made by Moses. A few examples, however, will have to suffice. In the field of law it is more than obvious, from a study of the common law of the ancient Near East, that Moses sanctioned many existing laws, giving them a new bent by making them the stipulations of Yahweh, Israel's God-king. In the field of cult it is reasonably certain that the Ark of the Covenant is adapted from Egyptian cult arks. Israel's feasts are for the most part either pre-mosaic feasts or baptized Canaanite feasts, but they are all 
given a new orientation. When the temple is built it is built by Phoenician architects: and in its appurtenances it will be for the most part similar to those of Canaanite temples.

Apart from the background knowledge it provides, the quotation is pertinent because Moses, upon whom it focuses, is acknowledged to be "the first of the great prophets" (Ellis, 1963:265). That tends to broaden the usual conception of who a prophet is. With specific reference to the existence of prophets in many other pre-Judaic religions, Blenkinsopp (1996:41) remarks:

The Hebrew Bible itself attests that prophecy was not confined to Israel. In the early years of the reign of Zedekiah, last king of independent Judah, Jeremiah is reported to have urged rulers from the neighbouring lands of Edom, Moab, Ammon, and the Phoenician cities, meeting in Jerusalem, not to heed their prophets, diviners and other intermediaries who were backing the planned rebellion against Nebuchadrezza (Jer. 27:1-3).

In the same vein, Boadt (1984:304) observes that "prophecy used to be considered a unique characteristic of Israel not found elsewhere in the ancient world". But he goes on to explain, "that view prevailed when the Bible was our only source of knowledge of the ancient world", this is no longer the case due to the fact that "since the last century, new information about prophecy in other nations has come to light". This insight can do nothing but smother a parochial view of prophecy.

\subsection{Prophecy in African traditional religion}

The foregoing clarifications are considered necessary to forestall doubts that prophecy exists outside Judaism and the associated religions of Christianity and Islam. Indeed, if prophecy is the divine art and act of informing people, including warnings and promises from God, through intermediaries (Preus, 2001:86), then it should not be supposed that prophecy does not exist in ATR. There seems to be no doubt that many traditional Africans seek to know the will of God through divination, which many scholars hold is an aspect of prophecy. In the words of Boadt (1984:305):

In the Bible itself, the earliest mention of prophetic roles comes in the form of divination to discover the divine will. The story of Gideon in Judges 6 tells how Gideon requested a sign from God by letting his fleece remain dry overnight while the ground nearby was covered with dew. 
With specific reference to ATR, Parrinder (1975:119) remarks that "divination or augury, foretelling the future by magical acts, is very popular in Africa", and that "geomancy, divining by figures on the earth, is found throughout the continent". He further observes that one writer has traced divination "from Senegal to Malagasy". It has also been noted that traditional African theology perceives reality holistically, with the belief that nothing whatsoever is possible unless ordained or permitted one way or another by God. As Awolalu and Dopamu (2005:16) state, Africans believe that the Supreme Being is living, omnipotent, omnipresent and omniscient. Ultimatele, that means that God is not only the source of every form of life, organic and non-organic alike, but $\mathrm{He}$ is also actively in control of all of life. Thus, in the African worldview even divination through magical acta is considered to be part of the resources with which humans are endowed by God.

\subsubsection{The function of prophecy in ATR}

The divinatory aspect of prophecy applies to political leadership in traditional Africa. It is adopted to determine, for instance, who becomes the king and to appoint public officers, such as chiefs, including the military Field Marshal. Writing on the African experience, with specific reference to the Yoruba of Western Nigeria, Idowu (1996:5) depicts a theocracy that is highly similar to what is found in the OT. In his words, as far as the Yoruba are concerned,

[t]he responsibility of all the affairs of life belongs to the Deity: their own part in the matter is to do as they are ordered through the priests and diviners whom they believe to be the interpreters of the will of the Deity. Through all the circumstance of life at every stage of life - puberty, bethrothal, marriage, taking up a career, building a house, going on a journey and, in fact, the thousand and one things which make up human existence here on earth - man is in the hands of the Deity whose dictate is law, and who is waiting on the other side of this life to render to him as he deserves.

There seems to be no doubt that this experience is common in the African worldview, and not limited to Yorubaland. Madubuike (2006:780) writes, for instance, that "there are many oracles in Igbo society, with each village having its own oracle as structural-functional mechanism". He (Madubuike, 2006:781) further comments that "There is the fear among Igbos that Onye aru nso ala (one who commits abomination or ritual pollution, witchcraft, killing, stealing, etc. cannot appear before the oracle)", because the person lacks ofo 
(justice), and "the oracle will deal with him or her". This practice appears similar to what is found in the OT, particularly when one thinks of the ministries of the prophets Samuel and Nathan, the leadership of Moses, the curious method of choosing Matthias to replace Judas Iscariot (Acts 1:26), and the deaths of Ananias and Sapphira, under the leadership of the apostles (Acts 5:1-11).

\subsubsection{Divine sovereignty in African perspective}

Unlike the deists who are said to believe in a remote creator, "uninvolved in the world whose mechanism he devised" (Williams, 1998:190), the widespread conception of God in ATR seems to be that God is the Alpha and the Omega Who decides and makes all things possible directly and indirectly (as in, for instance, Isa. 45:7). With regard to choosing political leaders, which is of special interest to this article, Fadipe (1978:254) notes that it is done in traditional Africa through spiritual consultations. Of course, that implies divination, which is considered to be a prophetic organ. Abe (2004:37 ff.) remarks that "the Africans believe that the society belongs to the Deity, and the various divinities have been given specific duties to sanitize the society". This is usually done one way or another through the agents, otherwise referred to as priests, diviners or prophets.

\section{Prophets in the OT and in ATR}

\subsection{Prophets in the OT}

Both in ATR and in the OT, prophecy is not merely concerned with enthroning political leaders. It also monitors the spiritual and moral rectitude of those anointed as well as the conduct of the entire populace. In the OT, the intervention of prophet Samuel is outstanding, particularly with reference to the institution of the Jewish monarchy, the enthronement of Saul, as well as his rebuke, dethronement, and eventual replacement of Saul with David (1 Sam. 9-15). Likewise, the sin of king David, and his reprimand by prophet Nathan (2 Sam. 11-12), which elicited David's repentance, signifies a clear instance of the chastising role of prophets in connection with political leadership and public morality. Häring (1979:353) writes:

The prophets most violently protested against the great evils of injustice, war, hatred, mercilessness and so on. The moral evils can cause a breakdown of faith in the God which a specific religion teaches if the representatives of that religion make no realistic protest against sins. 
Along that line, on a fundamental note, Shields (2004:65) explains that the ethical concern of the prophets derives from the fact that God is holy and righteous, and demands the same from his people. As Shields (2004:65) concludes, "righteousness and right behaviour clearly expressed the fact that a person knew and served God". That may not be better said, and the situation seems to be very similar in the traditional African perspective. Many scholars, such as Awolalu and Dopamu (2005:241), have noted that traditional Africans put a lot of emphasis on ethics, in respect of public, social and private morality. Political leaders and the general populace are cautioned, reprimanded, lampooned, warned or sanctioned, as the case may require by the ministers of God (the divinities) and their agents. Indeed, the agents can be as confrontational as their OT correspondents. In Yorubaland, with which the author is familiar, for example some masquerades (including Gèlèdé and Eégún Aláré) are known for their annual and occasional prophetic pronouncements, which rebuke evil perpetrators in a community. The Orò divinity agents do likewise.

\subsection{Critical prophecy in ATR}

In my observation no sacred cow (i.e. no highly or specially placed person) is recognised when a prophet (as mouthpiece of God and his divinities) is out to lampoon, rebuke, or pronounce judgement on people or individuals within a community. Prophetic pronouncements are made in plain talk, in songs or any other poetic form; and the prophet can emerge from any walk of life - a farmer, a hunter, a fisherman, a trader, et cetera. lyekolo (2006:98) notes, for instance, that "Mrs. Agberombi of Egbe was well known for her songs used to ridicule and correct societal vices." Egbe is a Yoruba town in Nigeria. There is hardly any doubt that critical prophecy and prophetic messages subsist in different forms in ATR, as imaginable with any authentic religion.

\subsection{Prophetic institutions in ATR and in the OT}

Like in the OT, prophecy is institutionalised in ATR when it is part of a religious system. However, it also exists independently, portraying God's absolute freedom of choice, when individuals, such as Amos who "was a sheep-farmer of Tekoa" in the OT was called by Yahweh and sent to prophesy to Israel without belonging to any prophetic brotherhood or family (Wansbrough, 1985:1179). God is also said to choose prophets from among the so-called pagans or heathens, just as Jesus is quoted as saying He found great faith among them (e.g. 
Matt. 8:5-10 and Luke 7:1-9). One of these prophets found in the OT is Balaam. Blenkinsopp (1996:41) notes:

An inscription roughly contemporary with Isaiah written in ink on plaster, discovered at Deir 'Alia in what was then the Ammonite Kingdom north of Moab, presents a 'Visionary of the gods' named Balaam who receives an ominous revelation from on high. Some connection with 'the one enraptured and with eyes unveiled' of the biblical Balaam cycle (Num. 22-24) is certain, though the homeland of the biblical Balaam is said to have been somewhere in Upper Mesopotamia (Num. 22:5; 23:7).

Thus, fundamentally, many well-informed biblical scholars do not seem to think that Israel had a monopoly on God-sent prophets. From the point of view of this article, one can infer that prophecy is comparatively similar in the OT and ATR. As Girigiri (2006:17 ff.) notes, politics, religion and ethics are symbiotically related in traditional Africa. In both the OT and ATR, as hitherto explained, prophecy serves as conscience and guide to both the leaders and their community and serves to prop-up both spirituality and morality, which are indispensable to social cohesion and development.

\section{Prophecy in the New Testament and in post-biblical Christianity}

The task here is to inquire into what prophecy entails in the New Testament (NT), and in Christianity as practiced outside the Scripture, in relation to political leadership. Jesus Christ is said to have functioned as a prophet, priest and king. In the words of The Catechism of the Catholic Church (Catechism, 1994:127), "Jesus fulfilled the Messianic hope of Israel in his threefold office of priest, prophet and king". What is more, the Catechism (1994:46) states that "God forms his people through the prophets". All that seems obvious to whoever is familiar with biblical theology. It is also evident that after the departure of Jesus, the remaining eleven apostles resorted to the divinatory aspect of prophecy when they cast lot after praying to determine who should replace Judas Iscariot, so as to maintain the number twelve. It would thus seem that the New Testament neither rejects nor demonises prophetic divination, with the imaginable exception of occultic divination.

\subsection{Occultic divination in Christian theological perspective}

There are Christian theologians, such as Peschke (a Catholic theologian), who do not object to occultic divination, but caution against 
excessive use and other negative aspects associated with it. Peschke (1981:98) notes:

The divining rod and the magic pendulum can doubtlessly be used by some persons to discover water, minerals, and at times even lost objects. Table turning can reveal hidden facts, although experts usually assure that it can only reveal with certainty those facts which are known, at least unconsciously, to one of the participants.

Moreover, according to Peschke (1981:101), "divination of occult knowledge seems admissible" for finding "lost objects or to gain information about missing persons". In other words, "divination of occult knowledge cannot simply be dismissed as irresponsible and sinful, if one is entitled to the knowledge, if there is no danger of harmful errors, and if the methods used are inoffensive". In the final consideration, Peschke (1981:102) warns:

Frequent indulgence in occultism constitutes a danger to faith and also to a person's psychological balance. Experience shows that much involvement in extra-sensorial practices can lead to mediumistic psychoses, which in extreme cases may even end in suicide attempts.

Of course, it is rightly said that anything done in excess is bad. And also that no amount or level of divination can make human beings see reality in its entirety as clearly as God, the Omniscient, can see it. ${ }^{2}$ At the same time it remains true that nothing ventured nothing gained. A person may learn and gain much from trials and errors within certain limits.

\subsection{Critical prophecy in the New Testament}

Based on the focus of this article, one is concerned that there seems to be less of a connection between the divinatory and socio-critical functions of prophecy and political leadership, when the NT is compared with the OT and ATR. As Ramsay (1986:2) writes "Jesus was more than a prophet, but he was a prophet", and "the New Testament tells us that there continued to be prophets in the early church", for instance "the prophets Agabus, Simon called Niger, Manaen, and others whose names we will never know, spoke for

2 The Yoruba of Western Nigeria say that he who knows everything becomes God. Of course, what that implies is that nobody can know everything, except God, the Omniscient. 
God to the first Christians". Beyond the fact that "the author of Revelation was a prophet", it is certain that "Paul was familiar with prophecy as one of the gifts of the Spirit". Notwithstanding these facts, Ramsay (1986:2) concludes:

\begin{abstract}
We do not have much clear information about prophets in the New Testament church, but we know quite well the work of the Old Testament prophets. They give us models of prophecy. When someone today speaks forth for God in the Spirit which animated the work of Amos, Isaiah and Jeremiah, we do well to listen. Their message of justice, wisely applied in that same Spirit, may indeed be thought of as God's prophetic word for our time.
\end{abstract}

It can thus be said, as far as political leadership is concerned, that the use of prophecy in the NT and Early Church was not as extensive as in the OT. That is probably because Christianity, unlike the OT and ATR, did not evolve with a political society, ab initio or from time immemorial. Indeed, many theologians have distinguished between the religion of Jesus (Judaism) and the religion about Jesus (Christianity). Crossan (2007:1) writes: "I have always thought of the historical Jesus as a homeland Jew within Judaism within the Roman Empire." Much more succinctly, Carrol (1991:15) observes that Jews and Christians do not share the same book nor do they share similar principles of interpretation. As he points out, "their ways of life and worship have little in common except the most superficial of resemblances". In concrete terms, Carrol draws attention to the fact that "a glance at a page of Talmud in comparison to a page from a Christian biblical commentary of the same period will speak volumes of the difference between the two". Of course, Jesus Christ was a Judaiser, while Christianity emerged in his name, after his ascension.

\title{
4.2.1 The prophetic role of Jesus
}

On the whole, Jesus' approach to his prophetic role seems to be somewhat different from the confrontational and politically involved models that characterise the OT and ATR. Ramsay (1986:4 ff.) notes the following about the OT "stories":

They told of Moses defying Pharaoh and crying in the name of the Lord, 'Let my people go'. They told of the prophet Nathan seeing an injustice and pointing at King David to announce, 'Thou art the man!' They told of the prophet Elijah who denounced King Ahab to his face when that tyrant had stolen a vineyard and condoned an illegal execution. They told the story 
of the prophet Elisha instigating a bloody political revolt against Queen Jezebel and her evil grandson on the throne.

Likewise, in the traditional African setting, prophets (mouth pieces of God and the divinities) go after evil doers, including kings and others in leadership positions. Bernheim and Bernheim (1968:13; cf. also Girigiri, 2006:18) aptly comment:

\begin{abstract}
Above the chief there sometimes is a king. In the old days, he was held to be sacred, and his face was often concealed from the sight of commoners. But even the king could not get away with injustice; in the Yoruba tribe he could be deposed, and when elders presented him with a bowl of parrot eggs, it was a discreet hint for him to disappear - or be killed.
\end{abstract}

The difference between the African and the Jewish approaches to critical prophecy seems to be a question of method, while the goal is identical: promotion of good political leadership. On the whole, it would seem that confrontation is inevitable in a world that is full of human wolves. Yet confrontation is only a part of the prophetic role, and it can take different, direct and indirect forms. With particular reference to Jesus, it seems incontrovertible that he was a classical prophet in the Judaic tradition in which prophets were expected to enjoin obedience to the will of God and exercise of love, mercy, and compassion in sisterly and brotherly relationships.

\title{
4.3 Prophecy in the ecclesiastical tradition
}

In contrast with the status of traditional Jewish prophecy, many scholars have noted how prophecy has suffered substantial setbacks in the history of the church. Blenkinsopp (1996:16 ff.) writes:

One of the most significant achievements of biblical scholarship in the nineteenth century was the rediscovery of prophecy as a distinctive religious category. The traditional Christian view, represented at that time by conservative and apologetic theologians like E.W. Hengstenbery and J.C.K. Horman, saw the prophets as forerunners and foretellers of Christ. Wellhausen, on the other hand, argued that Christ, who inherited the religion and ethic of the prophets, was betrayed by the institutional church in much the same way as the prophets had been betrayed by the ritualistic-legalistic system of early Judaism.

No wonder, then, that while the titles of priest, pastor, bishop, overseer, evangelist, and so on, are rampant, that of prophet is considered to be farfetched. Where prophets are said to exist in any explicit nomenclature, they are rarely comparable to the ancient 
authentic prophets. Commenting on an advertisement of a book, Prophecy and the twentieth century, Ramsay (1986:1) expresses disappointment that the material was one more book of fantastic speculations about "the rapture", "Armageddon", "the millennium", and how humanity was to prepare for "a last great battle", and so on. He notes that remembering "the words of the risen Christ in Acts 1:7 that we are not supposed to know about the divine timetable", prompted him to "[deposit] the advertisement in the trash". This seems to be the prevalent situation.

\subsubsection{Non-conventional christian prophets}

Some non-conventional christian prophets, such as William Wilberforce and David Livingstone, adopted the peaceful but critical approach of Jesus, and achieved some great ends. Wilberforce (17541833 ) is said to have spent his life working against slavery (Fajana, 1976:67), and he is rightly called "the liberator of the Negroes" (Ayandele, 1991:180). Hildebrandt (1996:115 ff.) indicates that Livingstone was the first person to draw attention to the inhuman condition of slaves, and the devastating effects of slave-raids on "tribes in eastern Africa". Similarly, Coutts (1990:65) refers to the fact that the christian faith had led some Christians to work for the upgrade of the position of "untouchables", while Latourette and Winter (1975:1019) note the efforts of many christian individuals and associations "to relieve suffering and to remedy collective evils". They (Latourette \& Winter, 1975:1336) point to the fact that the "Red Cross", an institution that relentlessly works for the alleviation of suffering "came into being through the efforts of a protestant layman of Geneva, Henri Dunant". Ordinarily, these individuals are not called prophets, yet a deeper view and analyses of their lives tend to qualify them as messengers of God, which is the nucleus of a prophet's vocation.

\subsubsection{Four modern christian critical prophets}

Ramsay's book (referred to above) furthermore reports on "four modern Christian prophets", namely Walter Rauschenbush, Martin Luther King Jr., Gustavo Gutierrez, and Rosemary Radford Ruether, all of whom, as he notes on page one, "proclaimed God's demand for justice for four different groups of people". That way, the four of them constituted, according to Ramsay, christian prophets who (among some others) stood up to rebuke and conscientise (in their various ways and contexts) the political leaders of their peoples. One wishes there were many more such prophets, to rebuke political leaders professionally or business-like, for the blooming 
fraud, exploitation of ordinary citizens, and general inhumanity of human beings to human beings that appear to pervade many contemporary societies, with particular reference to Africa.

\section{Prophecy, political leadership, and the church in Africa}

Literature reveals that divinatory activities are rife in Africa. A christian missionary, Fuller (2001:82) notes:

Muslims do divination, sometimes with patterns drawn in the sand or diagrams as keys written in Arabic. Christians have used a Bible or cross and the name of God to do incantations and divination, although the Bible forbids divination.

Thus, although many churches do not reckon with divination, in an official manner, the situation is different with many African Christians as individuals, and some churches that originated one way or another in Africa. Awolalu and Dopamu (2005:327) report on some churches in Africa:

They claim to give oracles and perform miracles. Prophets among them give visions and interpret dreams. They use holywater, sacred oil, ashes, candles and incense to heal and to prevent diseases. The cross has acquired a power which is almost magical. They offer prayers with persuasive, evocative and emotive language.

Awolalu and Dopamu (2005:327) identify such churches as "Independent African Churches", and they include such names as "the Apostolic Church, the Church of the Lord, the Cherubim and Seraphim, and the Celestial Church of Christ". Of course, many Africans who do not belong to the listed churches are also involved in divinatory activities, particularly during times of crisis.

\subsection{The imperative of critical prophecy in Africa}

The foregoing notwithstanding, it would seem that the divinatory method of prophecy has not been applied to political leadership in Africa by Christians, at least not at any official level that is known of. Indeed, there are many (though not all) christian theologians who do not recognise divination as a prophetic method, even though it is the art and act of deciphering the will of God and deities. Such conservative scholars limit prophecy to the critical aspect only. Preus (2001:86), for instance, may not be conservative in other 
respects, but as it pertains to the meaning of prophecy, he holds the following:

Generally speaking, prophecy interprets the spiritual meaning of present events, condemns wickedness, both open and hidden, and makes warnings or promises about what God is going to do within history. The prophets warn that the wrath of God is coming upon his own unfaithful, greedy, adulterous, and murderous people.

In point of fact, one would think that political leadership in Africa needs no more than prophets that conform with this definition presented by Preus. After all, religious plurality does not permit any particular religion the sole privilege of divining on who becomes a political leader. The real concern of this writer, therefore, is whether such prophets as described in Preus' definition are found in Christianity in Africa, and with what effects, spiritually and morally speaking.

\subsubsection{African non-conventional Christian prophets}

There seems to be no doubt that every African country has a number of christian prophets who, with or without a prophetic title, struggle for social justice, equity and charity. Ramsay (1986:91 ff.) observes that "in apartheid-ridden South Africa so many church leaders have spoken out on behalf of the oppressed that the white government there has had to arrest and imprison many". In specific terms, he notes that "the Nobel Peace Prize in 1984 went to an Anglican Bishop for his heroic stand for justice in that troubled country". 3 It stands to reason that there are African Christians who play the role of critical prophets without bearing the title.

\subsubsection{Dearth of critical prophecy in African Christianity}

It would certainly be desirable to have many christian leaders in Africa with the prophetic instinct and dexterity of Martin Luther King Junior and Archbishop Desmond Tutu. That is because, as Turaki (1997:19) notes, "human rights and its gross violation are testimonies against African Leadership". He laments further on page seventeen that "political leadership and political morality and ethics have been the major problems of African politics". The concern of this study is that there are not many christian prophets to rebuke

3 Referring to Archbishop Desmond Tutu and apartheid South Africa. 
erring African political leaders, decisively and frankly, as in the OT and ATR. The history of the prophetic movement in Africa is characterised by the burning of fetish objects and claims of casting out evil spirits. The life of William Wade Harris (a Liberian) who became a prophet after abandoning political activism, and started preaching and baptising converts, is a typical example (Beyer, 1998:8). Indeed, it cannot be said that the principles of critical prophecy have been sufficiently applied to Africa's socio-political and economic situation, overall. As Beyer (1998:20) points out, many churches avoid "reference to newspaper publications, or any matter of political nature, or one that affects government". That seems to be the prevalent christian approach in Africa, probably world over, generally speaking.

\section{The Christian and Muslim domination of Africa}

Beyond the foregoing, there is the realisation that christian prophets, even if they are many, may not be able to instil sanity into political leadership in Africa, without the collaboration of Muslims. There seems to be a consensus among many scholars that Christians and Muslims dominate socio-political and economic leadership in most countries in Africa. Oyeleye quotes an association, Islamic Women in Nigeria (IWN), as complaining about how political offices were shared lopsidedly between Christians and Muslims. In Oyeleye's (2007:13) words:

IWN condemned what it termed the prevailing sharing formula whereby the President is a Muslim, Vice President, a Christian, Senate President, a Christian, Deputy Senate President, a Christian, Speaker of the House of Representatives, a Christian, and her Deputy, a Muslim, making it a ratio two to four against the Muslim. They, however, proposed that in the interest of equity, fairness and justice, the key positions should be in the ratio of three to three namely, president a Muslim, vice-president, a Christian, Speaker, a Christian, and deputy Speaker, a Muslim.

Obviously, no consideration was given to ATR, since, like in most parts of Africa, it has been suppressed and marginalised, sociopolitically. Unfortunately, as Tasie (2003:1 ff,) notes, the Christians and Muslims who dominate the political scene

ride the religious ass, and manipulate it to suit their own purposes and agenda (often times hidden); and even when they cite the holy books and doctrines (whether it is in crusade, jihad 
or any other) as they often do, it is more often than not, manipulative.

This is the general assessment of the situation. In many churches and mosques, faith and miracle are emphasised to the extent that charity and compassion appear dead.

\subsection{The Christo-Islamic prophetic origins}

The foregoing sketches the need in Christianity and Islam for critical and corrective prophecy to be applied to political leadership in Africa. What is more, Shaikh (2006:70 ff.), an Islamic scholar, comments that (like Jesus) "Prophet Muhammed (SAAW) brought about a moral and intellectual revolution of unprecedented dimension", and "provided new systems of rights and responsibilities for the rulers and the ruled" (Shaikh, 2006:69). The concern here is that, socio-politically and economically speaking, the positive effects of the laudable teachings of Jesus and the Prophet are yet to be realised in many parts of Africa. Christians and Muslims would do well to speak prophetically for their divine Mentors.

\subsubsection{Africa's development under Christianity and Islam}

Both Christians and Muslims eulogise the holiness and the moral probity which they see in their respective divine leaders. They emphasise that the leaders lived, preached, and enjoined social justice, mercy, compassion, and charity. However, when we consider political leaders who claim to be Christians or Muslims, in whose hands are entrusted the resources and the socio-economic well-being of the peoples, it emerges that these virtues have not been applied to the running of private and public affairs in most African countries. It is hoped that critical prophecy, if adopted by Christians and Muslims, may fill the vacuum that is created by the marginalisation of ATR and its moral agents.

\subsubsection{Prophecy as a common element in all religions}

There seems to be no authentic religion without its prophetic organ. Every religion that is associated with the Supreme Being tends to have some socio-politically critical elements, even when the approaches may be different. In African context, critical prophetic message is sometimes given through some masquerades, while that may not apply in Christianity and Islam. What corresponds to the masquerade in the latter religions is when a priest, a pastor, or an imam delivers a prophetic message while in the appropriate regalia. However, the spiritual, ethical, and moral characteristics of the mes- 
sage are unmistakeably similar in promotion of human values, with particular reference to praising virtues and berating vices.

\title{
6.1.3 Critical prophecy in a religiously pluralistic society
}

In a religiously pluralistic society, such as is prevalent in Africa, no prophet of any particular religion is expected to dictate who becomes the ruler or public officer. Every society is expected to have constitutional parameters to determine who becomes a public officer. However, all authentic prophets of God and his divinities are identified with speaking for justice and charity, as well as condemning vices, toward a humane society. As Onaiyekan (2007:22 ff.) notes, good persons from all walks of life share the basic laws of charity, honesty, fair play, concern for others, and peaceful coexistence. One cannot agree less.

\section{The challenge of critical prophecy in Christendom}

Historically, as noted by some scholars, such as Blenkinsopp (see above), the church had, to a large extent, abandoned its prophetic role over a period of many centuries. This neglect can be attributed to the taking up of an imperialistic and autocratic lifestyle by the church. Renwick and Harman (2002:51) remark:

\begin{abstract}
With his growing power Constantino became more vain and self-complacent. He himself liked to be arrayed in splendid robes. It is not surprising, therefore, to find him presenting the bishop of Jerusalem with a set which vied in splendour with the best vestments of the pagan high priests. This is the first instance of the use of vestments in the Christian Church. The favours of the State, welcome as they were, tended to produce an arrogant spirit in the clergy.
\end{abstract}

Gradually but surely, the church allied itself with the Roman imperial authorities, and by the time separation became inevitable, it was difficult to distinguish between ecclesiastical and societal governments. Dulles (1978:39) notes that on the very eve of the Second Vatican Council, which was held from 1962-1965, Abbot B.C. Buttler wrote a book emphasising that "according to Roman Catholics the Church is essentially a single concrete historical society, having a constitution, a set of rules, a governing body, and a set of actual members who accept this constitution and these rules as binding on them". Of course, most churches are organised and structured as institutions that discipline and sanction disobedient, wayward or "heretical" members. 


\subsection{The alleged ecclesiastical abandonment of Jesus}

Since the church assumed the autocratic nature of imperial Rome, it tended to adopt similar measures, such as the persecution of socalled heretics, the inquisition, which included the burning of opponents, and wars, principally, the crusades. Yet, as Crossan (2007:4) reminds us, Jesus was "against Rome, then and now". Crossan could imagine hearing Jesus say to Pilate: "Your soldiers hold me, Pilate, but my companions will not attack you even to save me from death", and. "your Roman Empire, Pilate, is based on the injustice of violence, but my divine kingdom is based on the justice of nonviolence". Yet, upon its assumption of imperialism, the church tended to abandon the peaceful and nonviolent nature of Jesus. Beyond that, it started to persecute prophetic voices, such as Martin Luther, who kicked against simony, with particular reference to the indulgence that was designed to extort money from the laity. Schreck (1995:69) writes:

Indulgences were granted by the Church as a pledge of freedom from the effect of sin (i.e., punishment in purgatory) after a person died. Indulgences were supposed to be granted in recognition of a person's prayer or good works, but toward the end of the middle Ages, they were peddled like merchandise. The Dominican indulgence-seller Tetzel, who sparked Luther's protest against the Church, was reported to have chanted, 'as soon as a coin in the coffer rings, another soul to heaven springs'.

It would seem, fundamentally, that as long as the church or a church maintains an institutional structure and posture, it may never be as prophetic as it should be, since most institutions tend to strive to survive financially, and maintain their doctrines and laws with sanction. Allison (1994:38) documents "the inevitable provocations of institutional corruption" and its effects on the practice of Christianity. Another theologian, Dube (2003:53 ff.), expresses the conviction that for a Christian to live up to the prophetic vocation, he/she may have to be subversive as Jesus was in relation to the Jewish and Roman religio-political authorities. As she notes, Jesus should be emulated when He:

- questioned oppressive scriptures: if there are any scriptures used by church leaders and other believers to perpetuate the oppression of God's people, we are free to ask them, "Is it lawful to save life or to destroy it?"; 
- openly contested oppressive leaders: if our religious leaders and institutions give us policies and traditions that hinder our fight, we should be free to criticise these policies as oppressive and ungodly;

- was not afraid of the imperial rulers of his time.

That seems to be the heart of the matter for whoever is willing to take the critical prophetic path. As Jesus predicted: "If they persecuted me, they will persecute you too." (John 15:20.) One may end this with the Yoruba adage that reminds us that truth tellers are rarely accommodated.

\subsubsection{Fear of the church as an institution}

The first challenge to a christian prophet, therefore, may be the readiness to face the possible wrath of the church, in certain circumstances. The second challenge may be the political powers that be. Ramsay (1986:82) quotes Walter Rauschenbusch as stating that the crucifixion of Jesus was "a political assassination on the cross of collective apostasy by the political and religious institutions that claim authority over our lives". That seems to be what happened to the assassinated Archbishop Oscar Romero of San Salvador, when, as Brockman (1994:754-756) notes, he lost favour with the government, the majority of his fellow bishops, the papal nuncio, and apparently, "the Pope and his Curia", for his passionate opposition to the oppression and exploitation of ordinary compatriots. The impression is thus created that there is a church-state collusion against common people. In my experience in Nigeria, the situation is not different in comparison with Muslims and the state.

\subsubsection{The price of being a critical prophet}

Based on the foregoing, one would think it goes without saying that whoever cannot do without the patronage or favour of the church and partisan politicians; and whoever cannot endure persecution, may never be a critical prophet, as enjoined by biblical and African traditions. Yet, there seems to be no doubt that Africa needs such prophets for conscientisation and rebuke, with particular reference to political leaders who control both the human and material resources that can be harnessed for the development of the continent.

\section{Conclusion}

This study found that unlike Judaism and ATR, Christianity rarely applies its critical prophetic element to conscientise political 
leadership, ecclesiastically speaking. However, some heroes such as Walter Rauschenbusch, Martin Luther King, Jr., Gustavo Gutierrez, Rosemary Radford Ruether, Archbishop Oscar Romero, and Archbishop Desmond Tutu, are noted as evidence of exceptional individual cases. It was discovered that a person can be intimidated and scared away from embracing or persevering in critical prophecy, without courage and determination that is borne out of solid faith, to face persecution as fore-warned by Jesus. I raise the issue of the need for both christian and muslim leaders to deploy critical prophecy to engender good political leadership in Africa, since both Christianity and Islam dominate most African societies. Some scholars are quoted as holding that the two religions are not promoting public morality enough, with particular reference to political leadership, bribery and corruption, poverty and under-development in Africa. The author's recommendation is the adoption of critical prophecy by both Christians and Muslims, in order to promote social justice, equity, and charity. The findings of this study indicate the imperative of reviving the religious culture of reprimanding and lampooning tyrannical and exploitative rulers.

\section{List of references}

ABE, G.O. 2004. Yahwism tradition vis-a-vis African culture: the Nigerian milieu. Akungba-Akoko: Adekunle Ajasin University. (Inaugural lecture, series 1.)

ALLISON, C.F. 1994. The cruelty of heresy: an affirmation of christian orthodoxy. London: Society for Promoting Christian Knowledge.

ANON. 2009. Editorial. The Punch: 14, 6 Oct.

AWOLALU, J.O. \& DOPAMU, P.A. 2005. West African traditional religion. Lagos: Macmillan.

AYANDELE, E.A. 1991. The missionary impact on modern Nigeria, 1842-1914. London: Longman.

BERNHEIM, M. \& BERNHEIM, E. 1968. From bush to city: a look at the new Africa. New York: Brace \& World.

BEYER, E. 1998. New christian movement in West Africa. Ibadan: Sefer.

BLENKINSOPP, J. 1996. A history of prophecy in Israel. (Revised and enlarged ed.). Kentucky: Westminster John Knox.

BOADT, L. 1984. Reading the Old Testament: an introduction. New York: Paulist Press.

BROCKMAN, J. 1994. Romero, Oscar Arnufo (1917-1980). (In Glazier, M. \& HELLWIG, M.K., eds. The Modern Catholic Encyclopedia. Minnesota: The Liturgical Press. p. 754-756.)

CARROL, R.P. 1991. Wolf in the sheepfold: the Bible as a problem for Christianity. London: SPCK.

CATECHISM SEe THE CATECHISM OF THE CATHOLIC CHURCH

CATOIR, J.T. 1999. World religions: beliefs behind today's headlines. New York: Alba House. 
CONN, H.M. 1998. Liberation theology. (In Ferguson, S.B., Wright, D.F. \& Packer, J.I., eds. New Dictionary of Theology. Leicester: InterVarsity. p. 387-391.)

COUTTS, J. 1990. Our faith and theirs. London: Challenge Books.

CROSSAN, J.D. 2007. God and empire: Jesus against Rome, then and now. SanFrancisco: Harper.

DUBE, M.W. 2003. The prophetic method in the New Testament. (In Dube, M.W., ed. HIVIAIDS and the curriculum: methods of interpreting HIVIAIDS in theological programmes. Geneva: World Council of Churches. p. 4358.)

DULLES, A. 1978. Models of the church. New York: Image Books.

DZURGBA, A. 2006. Poverty in Africa today: a sociological perspective. (In Adelugba, D., Izevbaye, D. \& Ifie, J.E., eds. Wole Soyinka at 70: festschfirt. Lagos: Dat \& Partners Logistics. p. 733-768.)

ELLIS, P.F. 1963. The men and the message of the Old Testament. Minnesota: The Liturgical Press.

FADIPE, N.A. 1978. The sociology of the Yoruba. Ibadan: Ibadan University Press.

FAJANA, A. 1976. Nigeria and her neighbours. Book one. Lagos: African Universities Press.

FULLER, L. 2001. A missionary handbook on African traditional religion. Bukuru: Africa Christian Textbooks.

GIRIGIRI, B.K. 2006. Nigerian heritage: a historical and socio-cultural conceptualization. (In Anikpo, M.O.C. \& Atemie, J.D., eds. Nigerian sociocultural heritage. Port Harcourt: Amethyst \& Colleagues. p. 14-29.)

HÄRING, B. 1979. Free and faithful in Christ: moral theology for priests and laity. Vol. 2: The truth will set you free. Middlegreen: St. Paul publications.

HILDEBRANDT, J. 1996. History of the church in Africa: a survey. Achimota: Africa Christian Press.

IDOWU, E.B. 1996. Olodumare: God in Yoruba belief. Lagos: Longman.

IYEKOLO, E.B. 2006. The peoples of Okunland. Lagos: Concept Publications.

LATOURETTE, K.S., \& WINTER, R.D. 1975. A history of Christianity. Vol. 2: Reformation to the present. New York: Harper \& Row.

MADUBUIKE, S. 2006. Culture: the Igbo gerontocracy of social control. (In Adelugba, D., Izevbaye, D. \& Ifié, J.E., eds. Wole Soyinka at 70: festschrift. Lagos: Dat \& Partners Logistics. p. 769-793.)

OLUKOSHI, A. \& NYAMNJOH, F.B. 2007. Editorial. Codesria bulletin, (3 \& 4):13.

ONAIYEKAN, J.O. 2007. The Nigerian Christian in politics: notes for a talk. Abuja: Full Gospel Business Men's Fellowship International.

OYELEYE, B. 2007. Group challenges: Yar'Adua on appointments. The Nation, Lagos: 13, 22 Jun.

PARRINDER, G. 1975. African traditional religion. London: Sheldon.

PESCHKE, C.H. 1981. Christian ethics. Vol. 2: A presentation of special moral theology in the light of Vatican II. Dublin: Goodlife Neale.

PREUS, J. 2001. Reading the Bible through Christ: an introduction to exegesis and interpretation. Bukuru: African Christian Textbooks (ACTS) \& TCNN.

RAMSAY, W.M. 1986. Four modern prophets: Walter Rauschenbush, Martin Luther King, Jr., Gustavo Gutierrez, Rosemary Radford Ruether. Louisville: John Knox. 
RENWICK, A.M. \& HARMAN, A.M. 2002. The story of the church. Leicester: InterVarsity.

SCHRECK, N.A. 1995. The compact history of the Catholic Church. Bombay: St. Pauls.

SHAIKH, K.M. 2006. Da'wah in modern times. New Delhi: Ada.

SHIELDS, N. 2004. Christian ethics. Bukuru: Africa Christian Textbooks (ACTS).

SWEETLAND, D. 1994. Liberation theologies. (In Glazier, M. \& Hellwig, M.K., eds. The Modern Catholic Encyclopedia. Minnesota: The Liturgical Press. p. 505-510.)

TASIE, G.O. 2003. African culture, modern science and religious thought. (In Dopamu, P.A., Oyewole, S.O., Akanmidu, R.A., et al., eds. African culture, modern science and religious thought. Ilorin: African Centre for Religions and the Sciences (ACRS), University of llorin. p. 3-13.)

THE CATECHISM OF THE CATHOLIC CHURCH. 1994. Ibadan: St. Pauls.

TURAKI, Y. 1997. Tribal Gods of Africa. Jos: Crossroads Media Service.

WANSBROUGH, H. 1985. Introduction to prophets. The New Jerusalem Bible. Kinshasa: Verbum Bible.

WILLIAMS, S.N. 1998. Deism. (In Ferguson, S.B. \& Wright, D.F., eds. New Dictionary of Theology. Leicester: InterVarsity. p. 190.)

\section{Key concepts:}

African traditional religion

Christianity

divination

Islam

leadership

prophecy, critical

\section{Kernbegrippe:}

Afrika tradisionele godsdiens

Christenskap

Islam

leierskap

profesie, kritiese

waarsêery 